the views of those who find in popular spiritualism a system of thought and practice too crude to attract the more educated believer. As a well-balanced and judicious survey of the Society for Psychical Research past and present, this little book is to be highly commended. It shows the Society in what may be thought by some to be its best role, namely, a nucleus around which are gathered research workers of varied opinions who can use its platform for their results and get expert help and guidance when required for improving the quality of their work and assessing its value. The Society has had a long and distinguished career, and much of its published material is of the greatest value both to the psychologist and to the student of evidence and the value of testimony. To those who wish to inform themselves more fully of these aspects of the Society's work, no better introduction could have been devised than this little book.

\section{Learning and Industry}

A VALUABLE means of bringing about active co-operation between industry and the universities has recently been shown by the United Steel Companies, Ltd. At the invitation of the chairman, Sir Walter Benton Jones, fourteen mechanical and production engineering professors from British universities spent four days, beginning on April 12, in visiting the branches of the United Steel Companies at Sheffield, Scunthorpe and Stocksbridge, and in joint discussion both at the various works and at the Sheffield headquarters. Among the topics discussed were the design of Siemens open-hearth furnaces, the fuel balance of an integrated steelworks, and, led by Sir Charles Goodeve, director of the British Iron and Steel Research Association, some general research problems of the iron and steel industry. It was clear from the discussions that the research staff of the United Steel Companies were grateful for suggestions thrown out by the professors, while the latter were appreciative of the new problems put to them and which, in some cases, could usefully be followed up by them and their research staffs. By arranging this tour the United Steel Companies have shown a way in which industry and scholarship can work together for their mutual help and the well-being of British economy.

\section{Australia and New Zealand Association for the Advancement of Science}

THE report of the twenty-fifth meeting of the Australia and New Zealand Association for the Advancement of Science, held at Adelaide during August 1946, with its list of officers and research committees, balance sheet, constitution and by-laws, sectional transactions and reports of research committees, is something more than a useful reference work for the Association. In addition to Dr. P. Marshall's presidential address on "The Permanent Pacific" and Dr. Adrien Albert's Liversidge Centenary Lecture on "What can Chemistry Contribute to the Mastery of Disease ?", it includes the addresses of the sectional presidents. Some of the latter, such as those of Dr. Ian W. Wark to the Chemistry Section on "Australian Research on the Theory of Flotation", Dr. W. M. Bryan on "The Geological Approach to the Study of Soils", Dr. J. Pearson on "Some Problems of Marsupial Phylogeny", Dr. R. Wilson on "Facts and Fancies of Productivity", Dr. H. W. Bennetts on "The Pathological Approach to Problems of Animal Disease", and Prof. E. Ashby's "Survey of Botany in the Soviet Union" appear to be of notable scientific interest and deserve the wider audience that they can now reach. Among other addresses included are those of R. Lemberg on "New Aspects of the Theory" of Function of Respiratory (Hæmatin) Enzymes", A. Gottschalk on "Some Aspects of the Relationship between Chemical Structure and Enzyme Specificity", and of A. T. S. Sissons on "The Widening Front of Pharmaceutical Science".

\section{Archæology in South Africa}

The report for 1946-47 of the Archæological Survey of the Union of South Africa has been published (Johannesburg). The most interesting piece of information therein is that the Little Caledon River has apparently cut its bed down some $300 \mathrm{ft}$. through Beaufort Sandstone since the occupation of the upper part of the valley by early Stellenbosch man. Sandstone, of course, is not such a hard material as basalt; nevertheless, a long period of time must be postulated since early man lived in those regions. Dr. van Riet Lowe has published a note in the South African Archoological Bulletin, 2, Pt. 8 (1947) on some interesting tanged and winged arrow-heads. This type of tool has not been found heretofore in the Union. Dr. van Riet Lowe assigns them, no doubt rightly, to a Neolithic stage of development. $\mathrm{He}$ does mention, incidentally, the discovery of somewhat similar arrow-heads in a so-called Solutrean milieu in eastern Spain; but it may be premature to assign Dr. Pericot's finds definitely to the European Solutrean culture. Spanish prehistory south of the northerm mountain ranges looks mainly to North Africa for its connexions. Maybe the word Aterian will have to be substituted for Solutrean eventually. But the occurrence of tanged and winged arrowheads in the South African Neolithic is indeed an interesting addition to knowledge.

\section{Identification of Important Indian Timbers}

IF any one factor could be picked out as justifying forestry research in the tropical and sub-tropical forest containing many timber species growing in mixture, it would consist in some popular means of identifying the various kinds. This problem first presented itself in India during the First World War, when many species of timber, practically previously unmarketable, came into use. The demand on the Indian forests was far greater in the Second World War. For the use of the Army, six leaflets entitled "How to Identify Timbers" were issued from Dehra Dun. These have now been collected together into Indian Forest Record (Utilisation), Vol. 3, No. 7, by the wood technologist of the Forest Research Institute, and keys and photomicrographs of the timbers that are commercially available in the different military zones of inspection have been added. The photomicrographs, on which 114 timbers are shown in 57 plates, are very clear. The writer says they will be as useful to the commercial trader as to the military authorities; he might have added also to the district forest officer and his staff in part $s$ of the country where new timbers, previously unmarketable, are now commercially salable.

\section{The Food of Humming-Birds}

AN excellent monograph on the feeding and related behaviour of humming-birds (with special reference to the black-chin, Archilocus alexandri) was prepared by Frank Bené before his death in 1943 